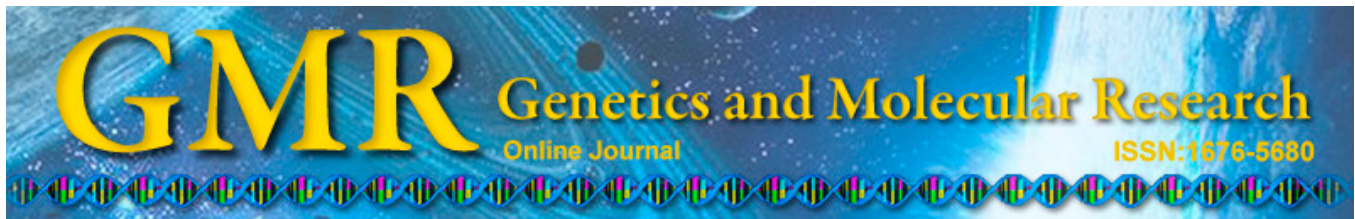

\title{
Genetic diversity among Puccinia melanocephala isolates from Brazil assessed using simple sequence repeat markers
}

R.F. Peixoto-Junior ${ }^{1}$, S. Creste ${ }^{2}$, M.G.A. Landell ${ }^{2}$, D.S. Nunes ${ }^{2}$,

A. Sanguino ${ }^{2}$, M.F. Campos ${ }^{2}$, R. Vencovsky ${ }^{3}$, E.V. Tambarussi ${ }^{3}$ and

A. Figueira ${ }^{1}$

${ }^{1}$ Centro de Energia Nuclear na Agricultura, Universidade de São Paulo, Piracicaba, SP, Brasil

${ }^{2}$ Centro de Cana, Instituto Agronômico de Campinas, Ribeirão Preto,

SP, Brasil

${ }^{3}$ Escola Superior de Agricultura "Luiz de Queiroz", Universidade de São Paulo,

Piracicaba, SP, Brasil

Corresponding author: S. Creste

E-mail: screste@iac.sp.gov.br

Genet. Mol. Res. 13 (3): $7852-7863$ (2014)

Received February 12, 2014

Accepted May 27, 2014

Published September 26, 2014

DOI http://dx.doi.org/10.4238/2014.September.26.23

ABSTRACT. Brown rust (causal agent Puccinia melanocephala) is an important sugarcane disease that is responsible for large losses in yield worldwide. Despite its importance, little is known regarding the genetic diversity of this pathogen in the main Brazilian sugarcane cultivation areas. In this study, we characterized the genetic diversity of $34 P$. melanocephala isolates from 4 Brazilian states using loci identified from an enriched simple sequence repeat (SSR) library. The aggressiveness of 3 isolates from major sugarcane cultivation areas was evaluated by inoculating an intermediately resistant and a susceptible cultivar. From the enriched library, 16 SSR-specific primers were developed, which produced scorable alleles. Of these, 4 loci were polymorphic and 12 were monomorphic for all isolates evaluated. The molecular 
characterization of the 34 isolates of $P$. melanocephala conducted using 16 SSR loci revealed the existence of low genetic variability among the isolates. The average estimated genetic distance was 0.12 . Phenetic analysis based on Nei's genetic distance clustered the isolates into 2 major groups. Groups I and II included 18 and 14 isolates, respectively, and both groups contained isolates from all 4 geographic regions studied. Two isolates did not cluster with these groups. It was not possible to obtain clusters according to location or state of origin. Analysis of disease severity data revealed that the isolates did not show significant differences in aggressiveness between regions.

Key words: Brown rust; Genetic diversity; Microsatellite; Sugarcane; Puccinia melanocephala; Simple sequence repeat

\section{INTRODUCTION}

Sugarcane brown rust, caused by the basidiomycete Puccinia melanocephala H. \& P. Sydow, is an important sugarcane (Saccharum spp) disease that is responsible for large yield losses worldwide. This pathogen now occurs in all regions where sugarcane is cultivated worldwide, but it was only recently introduced to the Americas (Whittle and Holder, 1980). Its ability to produce large numbers of infectious spores (uredinospores) asexually, which are adapted for aerial transport, is responsible for determining severe losses in susceptible cultivars. Sexual recombination is recognized in other Puccinia species, although the sexual stage has not been described for P. melanocephala. In July 1978, P. melanocephala was first identified in the Dominican Republic, marking the beginning of the brown rust epidemic in the Americas (Purdy et al., 1983). P. melanocephala is thought to have reached the Americas via wind currents from Cameroon, West Africa, which is the nearest source of inoculum. Until then, this pathogen was present in scattered localized areas in Africa and Asia and did not cause significant damage. Only after introduction into the Americas, the disease became economically important (Purdy et al., 1983). In the same year, brown rust was also detected in Queensland, Australia, and rapidly spread to all areas that cultivated sugarcane, severely affecting the main cultivated varieties (Taylor, 1992). The introduction of $P$. melanocephala in Australia can be attributed to the monsoon winds that are able to carry the spores from a close source across the Indian Ocean (Whittle and Holder, 1980). In Brazil, brown rust was first detected in 1986 near Capivari in São Paulo State in the largest producing region (Amorim et al., 1987). In a short period of time, the disease was detected in Pernambuco and Alagoas states, more than $2000 \mathrm{~km}$ away from São Paulo.

The existence of $P$. melanocephala races has not been reported in Brazil, but races have been identified in other regions. For instance, 4 races of $P$. melanocephala were identified in Lousiana, USA (Shine et al., 2005), but no race has been detected in Australia (Taylor, 1992).

In countries, where sugarcane is widely cultivated, and, therefore, subject to large $P$. melanocephala populations and edapho-climatic conditions, it is imperative to understand the range of the genetic diversity of this pathogen. This information may provide significant information related to the pathosystem. Thus, understanding the genetic diversity of the pathogen in the main cultivation areas, together with processes that affect diversity, are required for de- 
veloping breeding strategies. Because of the inherent biological characteristics of rust spores and disease epidemics, many rust pathogens are recognized for their long-distance dispersal, following either a single aerial transport event or stepwise range expansion from a source into new regions (Isard et al., 2011).

DNA markers have been widely adopted for analyzing the dynamics of plant pathogen populations because of their high levels of precision and accuracy (Milgroom and Peever, 2003). Simple sequence repeats (SSR) or microsatellite sequences are relatively abundant and evenly distributed in eukaryote genomes (Weising et al., 1995). Notably, fungal genomes appear to contain fewer SSR sequences than other eukaryotes (Dutech et al., 2007); however, when polymorphic loci are available, they can be very useful for genome mapping and genetic diversity and population genetic studies, which warrant the search and development of such genetic markers. The objectives of this study were to develop SSR loci from a P. melanocephala enriched genomic library and explore their potential for evaluating the genetic diversity of $P$. melanocephala isolates from the main sugarcane production regions in Brazil. Additionally, the aggressiveness of isolates from 3 important sugarcane cultivation regions was evaluated by artificial inoculation.

\section{MATERIAL AND METHODS}

\section{Sampling and identification of rust isolates}

Sugarcane leaf segments exhibiting typical symptoms of brown rust were collected from 4 Brazilian States (São Paulo, Minas Gerais, Goiás, and Alagoas), which represent the main sugarcane cultivation regions in Brazil. A total of 34 isolates were obtained from 4 Brazilian states (Table 1). All leaf samples were examined under a microscope to evaluate uredinium and urediniospore structures that characterize P. melanocephala (Virtudazo et al., 2001a; Dixon et al., 2010).

\section{Construction of SSR locus-enriched library}

Genomic DNA was extracted from urediniospores from P. melanocephala isolated from the cultivar 'RB835486' collected at "Centro de Cana" at Ribeirão Preto, SP (Aljanabi et al., 1999). Fresh urediniospores were collected from pustules (uredinia) present on the abaxial leaf side using a vacuum pump. The SSR locus-enriched library was developed using biotinylated oligonucleotide sequences bound to streptavidin-coated magnetic particles (Creste et al., 2006). Briefly, $5 \mu \mathrm{g}$ genomic DNA was digested with $R s a \mathrm{I}$, and a sample of $600 \mathrm{ng}$ was ligated to adaptors (Rsa21: 5'-CTCTTGCTTACGCGTGGACTA-3'; Rsa25: 5'-TAGTCCACG CGTAAGCAAGAGCACA-3'). The ligated fragments were then amplified by polymerase chain reaction (PCR) and products were allowed to hybridize to biotinylated $\mathrm{I}_{5}(\mathrm{CT})_{8}$ and $\mathrm{I}_{5}(\mathrm{GT})_{8}$ probes, which were later recovered by Streptavidin MagneSphere Paramagnetic Particles (Promega, Madison, WI, USA). The eluted fragments were re-amplified using the Rsa21 primer and cloned into the pGEM-T Easy vector (Promega). Plasmids were transformed into Escherichia coli XL1-Blue cells. Positive clones were sequenced using the M13 primer and BigDye terminator Cycle Sequencing Kit (Applied Biosystems; Foster City, CA, USA) in a 3100 DNA Analyzer. Primers were designed using Primer3 (http://bioinfo.ut.ee/ primer3-0.4.0), and primer quality was evaluated using Netprimer (http://www.premierbiosoft.com/netprimer/netprimer.html). 
Table 1. Sugarcane cultivars, regions $(\mathrm{AL}=$ Alagoas; $\mathrm{GO}=$ Goias; $\mathrm{MG}=$ Minas Gerais; $\mathrm{SP}=$ São Paulo $)$ and years of isolation of Puccinia melanocephala isolates.

\begin{tabular}{|c|c|c|c|}
\hline Isolate & Host & Origin & Year of isolation \\
\hline P201 & RB85 5486 & Pontal, SP & 2010 \\
\hline P204 & SP79 1011 & Santa Lúcia, SP & 2010 \\
\hline P207 & IAC84 2480 & Mococa, SP & 2010 \\
\hline P210 & SP70 1143 & Conchal, SP & 2010 \\
\hline $\mathrm{P} 213$ & IAC86 2480 & São João da Boa Vista, SP & 2010 \\
\hline P217 & IACSP98 5024 & Batatais, SP & 2010 \\
\hline P219 & RB83 5486 & Pompeu, MG & 2010 \\
\hline $\mathrm{P} 222$ & CTC 11 & Lençóis Paulistas, SP & 2010 \\
\hline P225 & IAC84 2480 & Itápolis, SP & 2010 \\
\hline P228 & IACSP97 6682 & São Joaquim da Barra, SP & 2009 \\
\hline $\mathrm{P} 231$ & RB83 5486 & Patos de Minas, MG & 2010 \\
\hline $\mathrm{P} 234$ & IAC84 2480 & Pindorama, SP & 2010 \\
\hline P237 & RB83 5486 & Catanduva, SP & 2010 \\
\hline P240 & IACSP95 1218 & Santa Lúcia, SP & 2010 \\
\hline P243 & SP79 1011 & Olímpia, SP & 2010 \\
\hline P246 & RB 835486 & Guaíra, SP & 2010 \\
\hline P249 & IAC87 3396 & Patos de Minas, MG & 2010 \\
\hline P252 & RB83 5486 & Itápolis, SP & 2010 \\
\hline $\mathrm{P} 255$ & IAC91 5155 & Goianésia, GO & 2010 \\
\hline P258 & IAC91 5155 & Jaú, SP & 2011 \\
\hline P261 & IAC97 6682 & Goianésia, GO & 2011 \\
\hline P264 & SP79 1011 & Goianésia, GO & 2010 \\
\hline P267 & SP70 1143 & Goianésia, GO & 2010 \\
\hline $\mathrm{P} 270$ & IAC97 6682 & Goianésia, GO & 2010 \\
\hline P273 & IAC86 2480 & Jaú, SP & 2011 \\
\hline $\mathrm{P} 300$ & IAC86 2480 & Jaú, SP & 2010 \\
\hline P303 & IAC87 3396 & Ribeirão Preto, SP & 2010 \\
\hline P306 & IAC91 5155 & Ribeirão Preto, SP & 2011 \\
\hline P309 & IAC86 2480 & Ribeirão Preto, SP & 2010 \\
\hline P312 & IAC86 2480 & Indiara, GO & 2010 \\
\hline P315 & SP71 6949 & São José da Laje, AL & 2010 \\
\hline P318 & SP78 4264 & São José da Laje, AL & 2010 \\
\hline $\mathrm{P} 321$ & SP86 42 & Jaboticabal, SP & 2010 \\
\hline $\mathrm{P} 324$ & IACSP03 8145 & Orindiuva, SP & 2010 \\
\hline
\end{tabular}

\section{Characterization of $P$. melanocephala isolates using SSRs}

DNA was extracted from a suspension of urediniospores from 1 single pustule from the P. melanocephala isolates (Virtudazo et al., 2001b). Approximately 300-400 urediniospores were collected and ground using a glass stick in a tube containing $200 \mathrm{~mL}$ buffer $(50$ $\mathrm{mM} \mathrm{KCl} ; 10 \mathrm{mM}$ Tris- $\mathrm{HCl}, \mathrm{pH} 8.0 ; 1.5 \mathrm{mM} \mathrm{MgCl}_{2} ; 0.01 \%$ proteinase $\mathrm{K}$ ). Next, the suspension was incubated at $37^{\circ} \mathrm{C}$ for $1 \mathrm{~h}$ followed by $95^{\circ} \mathrm{C}$ for $15 \mathrm{~min}$ and subsequently stored at $4^{\circ} \mathrm{C}$ to be used later for SSR amplification. The amplification reactions contained $1 \mathrm{~mL}$ urediniospores suspension in a 20 - $\mathrm{mL}$ final reaction volume, containing buffer $(100 \mathrm{mM} \mathrm{KCl}$; $20 \mathrm{mM}$ Tris-HCl, $\mathrm{pH}$ 7.4; $1 \mathrm{mM}$ DTT; $0.1 \mathrm{mM}$ EDTA; $200 \mathrm{mg} / \mathrm{mL}$ bovine serum albumin), $1.5 \mathrm{mM} \mathrm{MgCl}, 0.05 \mathrm{mg} / \mathrm{mL}$ casein, $200 \mathrm{mM} \mathrm{dNTP}, 1 \mathrm{mM}$ of each primer, and $1 \mathrm{U}$ Phire Hot Start DNA Polymerase (Finnzymes Oy; Espoo, Finland). Amplifications were performed in a MyCycle thermocycler (Bio-Rad; Hercules, CA, USA) using the touchdown PCR program, comprised of an initial step of $3 \mathrm{~min}$ at $95^{\circ} \mathrm{C}$, followed by 9 cycles of $40 \mathrm{~s}$ at $94^{\circ} \mathrm{C}, 40 \mathrm{~s}$ at annealing temperature decreased from $60^{\circ}-50^{\circ} \mathrm{C}$ by $1^{\circ} \mathrm{C}$ every cycle, and $60 \mathrm{~s}$ at $72^{\circ} \mathrm{C}$, followed by 30 identical cycles, except for the annealing temperature at $50^{\circ} \mathrm{C}$ for $40 \mathrm{~s}$. 


\section{SSR locus data analysis}

Amplified SSR fragments were scored in terms of loci and alleles. Relationships among the isolates were evaluated using phenetic cluster analysis with unweighted pairgrouping and arithmetic average clustering using Nei's unbiased (Nei, 1973) genetic distance. The results were plotted in a dendrogram using NTSYS-PC version 2.0j (Exeter Software, Setauket, NY, USA). Bootstrap analysis (Efron, 1981) was performed using the Winboot program (Yap and Nelson, 1996) with 1000 repetitive samplings of SSR data to compute bootstrap P values. The polymorphism information content (PIC) was estimated for each locus by $\mathrm{PIC}=1-\mathrm{SPi}^{2}$, where $P i$ was the frequency of allele $i$ within the population (Anderson et al., 1993). The coefficient of correlation (r) was computed between genetic and geographic distances, considering all pairs of locations. The significance of $\mathrm{r}$ was found using the Mantel $\mathrm{Z}$ test (Mantel and Valand, 1970).

\section{Evaluation of aggressiveness of $P$. melanocephala}

The aggressiveness of $P$. melanocephala was evaluated using 3 isolates from the main sugarcane Brazilian cultivation regions. Urediniospores P261 (Goianésia, GO), P273 (Jaú, SP), and P306 (Ribeirão Preto, SP) were maintained and multiplied in leaves of the susceptible cultivar 'SP701143' under greenhouse conditions. Individual buds were planted in 3-L pots containing a 3:1:1 mixture of soil, sand, and substrate (pine and coconut bark-Tropstrato) and grown in a greenhouse until inoculation. Initially, 30-day-old plants were kept in a humid growth chamber for $12 \mathrm{~h}$. Subsequently, the abaxial face of leaves was sprayed with a solution of $2 \times 10^{4}$ urediniospores $/ \mathrm{mL}$ from each of the 3 regions (Garcia et al., 2007). After inoculation, samples were kept in humid growth chamber for $24 \mathrm{~h}$. Next, plants remained protected in a chamber, separated by regions to enable spore maintenance and multiplication.

To evaluate differences in aggressiveness among P. melanocephala isolates, inoculations were conducted on excised leaves (Garcia et al., 2007). The abaxial side of a $20-\mathrm{cm}$ segment of the +1 leaf of cultivars 'SP701143' (susceptible) and 'RB835486' (intermediately resistant) was sprayed with a solution of $2 \times 10^{4}$ viable urediniospores $/ \mathrm{mL}$. Inoculated leaf segments were then transferred to $25-\mathrm{cm}$ width test tubes, filled with $3 / 4$ volume distilled water, and sealed. Tubes for each treatment were kept at $21^{\circ} \mathrm{C}$ under a 12 -h photoperiod for 15 days. Symptom severity was evaluated 14 days after inoculation using a diagrammatic scale (Amorim et al., 1987). The experimental design consisted of 4 treatments ( 3 isolates plus a control) in a completely randomized design with 5 replicates (test tube containing 1 inoculated leaf segment). The control treatment consisted of leaf segments inoculated with sterile distilled water. For statistical analysis, the original data were transformed by $\sqrt{ }(x+0.5)$, where $\mathrm{X}=\%$ infected leaf area, and subjected to analysis of variance and the Tukey test for mean comparisons.

\section{RESULTS}

\section{SSR locus-enriched library}

A library containing 384 clones was obtained for P. melanocephala and enriched for 2 types of SSR motifs (CT and GT). Of the 178 clones sequenced, $52.2 \%$ were found to con- 
tain SSRs, of which $15.1 \%$ had more than 1 SSR within the same region, resulting in a total of 135 SSR loci. Of the SSR loci identified, the most frequent dinucleotide motif observed was GT/TG (20.7\%), followed by CA/AC (15.5\%), GA/AG (5.2\%), TA/AT (3.0\%), and CT/ TC (2.2\%). Trinucleotide repeat motifs were identified and were found to account for $19.2 \%$ of the total. Tetranucleotide (TAAT and TTTA; 1.5\%), pentanucleotide (TTGGG; 0.8\%), and hexanucleotide (ACACGC; $0.8 \%$ ) motifs were also observed. Only 4 sequences showed SSR motifs interrupted with non-repeated motifs. Mononucleotides were identified with only A- or T-repeat motifs ranging from 8-15 times, but these were not included in the primer design because mononucleotide SSRs generally show low polymorphism (Tóth et al., 2000). SSRs with dinucleotide motifs were observed ranging from 8 repeats (set as the lowest cutoff) to 37 repeats, whereas tri- and tetranucleotide motifs ranged from 4-13 and 6-8 repeats, respectively.

\section{Characterization of the SSR loci}

A set of 21 pairs of primers was developed from the enriched SSR library. Sixteen (72.6\%) produced well-defined discrete fragments, whereas 5 failed to show amplification. Of the 16 primer pairs producing scorable products, 4 (25\%) were polymorphic and $12(75 \%)$ were monomorphic for all isolates tested (Table 2). The number of alleles per locus ranged from 1-5, with a total of 34 alleles and an average of 2.1 alleles per locus. Of the 4 loci containing polymorphisms, a total of 18 alleles were obtained, with an average of 4.5 alleles per polymorphic locus (Table 2). The PIC of the 16 loci ranged from $0-0.64$, with an average of 0.45. Loci $m P m I A C 101, m P m I A C 103, m P m I A C 107$, and $m P m I A C 111$ were characterized as informative loci (PIC > 0.5); mPmIAC105, mPmIAC108, mPmIAC112, mPmIAC114, $m P m I A C 116$, and $m P m I A C 120$ were considered to be moderately informative $(0.25>$ PIC $>0.5)$, and mPmIAC109, mPmIAC110, mPmIAC113, mPmIAC115, mPmIAC118, and $m P m I A C 119$ were considered to be not informative (PIC $<0.25$ ) (Botstein et al., 1980). The amplified loci displayed alleles of expected fragment sizes, and the greatest allele amplitude was observed for $m P m I A C 105$, with alleles ranging from 188-246 bp.

\section{Genetic diversity among $P$. melanocephala isolates}

Molecular characterization of the 34 isolates of $P$. melanocephala conducted with 16 SSR loci revealed low genetic variability among the isolates. Based on phenetic analysis, we clustered the 34 isolates into 2 main distinct groups, from which several subgroups were derived (Figure 1). Group I consisted of 18 isolates, while group II contained 14 isolates, and both groups were composed of isolates from all 4 Brazilian states evaluated. The isolates P312 (Goianésia, GO) and P201 (Pontal, SP) were more distant from the others and were clustered as an out-group. The dendrogram shows that within group I, some isolates were genetically identical based on the loci evaluated, including P264 (Goianésia, GO) and P246 (Guaíra, SP); P217 (Batatais, SP) and P321 (Jaboticabal, SP); P210 (Conhal, SP) and P222 (Lençóis Paulista, SP). It was not possible to cluster the isolates according to location or state of original collection. The highest genetic distance observed was 0.31 between the isolates P309 (Ribeirão Preto, SP), P324 (Orindiuva, SP), P334 (Pindorama, SP), and P255 (Goianésia, GO). The average estimated genetic distance was 0.12 . No association between genetic and geographic distances was observed (Figure 2). 


\begin{tabular}{|c|c|c|c|c|c|c|c|}
\hline Locus & Primer sequence $\left(5^{\prime}-3^{\prime}\right)$ & Repeat motif & $\mathrm{T}\left({ }^{\circ} \mathrm{C}\right)$ & $\begin{array}{l}\text { Original cloned } \\
\text { allele (bp) }\end{array}$ & $\begin{array}{l}\text { Allele size } \\
\text { range (bp) }\end{array}$ & $\mathrm{N}$ & PIC \\
\hline mPmIAC101 & $\begin{array}{l}\text { F: CGTGTCAACCTATCAACCTG } \\
\text { R: CTCCACAACACTACAACCTG }\end{array}$ & $(\mathrm{GT})_{8}$ & 55 & 248 & $232-248$ & 5 & 0.64 \\
\hline mPmIAC102 & $\begin{array}{l}\text { F: GCACCATTCACAAACAGC } \\
\text { R: CACACACCACACGAGAGTAA }\end{array}$ & $(\mathrm{AGA})_{6}$ & 55 & 173 & NA & - & - \\
\hline mPmIAC103 & $\begin{array}{l}\text { F: TACCGCCGACAGATTTAC } \\
\text { R: ATACACAAGCGTGGGAGA }\end{array}$ & $(\mathrm{TC})_{17}$ & 55 & 195 & $185-198$ & 4 & 0.59 \\
\hline mPmIAC104 & $\begin{array}{l}\text { F: ATAGACGCAATGGAAGAAAC } \\
\text { R: ACACACACAAACGCTTACAA }\end{array}$ & $(\mathrm{AC})_{10}$ & 55 & 183 & NA & - & - \\
\hline mPmIAC105 & $\begin{array}{l}\text { F: GAGAAGGAGTGAGAAGGAAA } \\
\text { R: TAACCGCGTCTTAGCAAC }\end{array}$ & $(\mathrm{AG})_{9}$ & 53 & 246 & $188-246$ & 2 & 0.37 \\
\hline mPmIAC106 & $\begin{array}{l}\text { F: CGACCGCTTATGATAGAGTA } \\
\text { R: GTCTGTGTGATTGAGATTGC }\end{array}$ & $(\mathrm{CA})_{23}$ & 53 & 227 & NA & - & - \\
\hline mPmIAC107 & $\begin{array}{l}\text { F: GGGCGTAATGAAACTCTG } \\
\text { R: ATTCGGACGACCACAAAC }\end{array}$ & $(\mathrm{AC})_{14}$ & 55 & 250 & $246-252$ & 4 & 0.51 \\
\hline mPmIAC108 & $\begin{array}{l}\text { F: GACGCCTGGAATGAGAGAAC } \\
\text { R: GGCTACTTCCTGGTCCGATA }\end{array}$ & $(\mathrm{TC})_{18}$ & 60 & 161 & $155-161$ & 2 & 0.37 \\
\hline mPmIAC109 & $\begin{array}{l}\text { F: TGCGTGTATTCGTGAGTTCG } \\
\text { R: CGTCGCTTCCATCCGTTAT }\end{array}$ & $(\mathrm{GT})_{7}$ & 60 & 245 & 245 & 1 & 0.00 \\
\hline mPmIAC110 & $\begin{array}{l}\text { F: TCGATTGCTGTCCTGATTCC } \\
\text { R: GCTCGCTCTCGGTAACTTTCT }\end{array}$ & $(\mathrm{AG})_{16}$ & 60 & 212 & 112 & 1 & 0.00 \\
\hline mPmIAC111 & $\begin{array}{l}\text { F: CGAGGTGAAACGATGGAAA } \\
\text { R: AGGCGGGCATACAAAAATAG }\end{array}$ & $(\mathrm{AT})_{8}$ & 60 & 249 & $220-249$ & 5 & 0.50 \\
\hline mPmIAC112 & $\begin{array}{l}\text { F: GAGGCAGGCAGTGAGAGA } \\
\text { R: CTGGAGATGGTGATGCTATG }\end{array}$ & $(\mathrm{AG})_{17}$ & 57 & 246 & $225-246$ & 2 & 0.37 \\
\hline mPmIAC113 & $\begin{array}{l}\text { F: AGTCATAAAAACCGTCCAAC } \\
\text { R: CGTGTCAGTCCTTCAGAGA }\end{array}$ & $(\mathrm{CA})_{10}$ & 55 & 171 & 171 & 1 & 0.00 \\
\hline mPmIAC114 & $\begin{array}{l}\text { F: GACTTGCGACTGGTGAATGA } \\
\text { R: GTGACGAGTGCTTGCTACGA }\end{array}$ & $(\mathrm{TG})_{29}$ & 60 & 175 & $178-210$ & 2 & 0.37 \\
\hline mPmIAC115 & $\begin{array}{l}\text { F: GACGGACAGATAGACTTTTCAC } \\
\text { R: ATCACTCTCCCCTTTCTCAC }\end{array}$ & $(\mathrm{GT})_{16}$ & 55 & 165 & 155 & 1 & 0.00 \\
\hline mPmIAC116 & $\begin{array}{l}\text { F: CGCGCTACACTACGTTTAAG } \\
\text { R: ACACTGCTCACTCACACACC }\end{array}$ & $(\mathrm{AAT})_{6}$ & 56 & 136 & $136-138$ & 2 & 0.37 \\
\hline mPmIAC117 & $\begin{array}{l}\text { F: GTGCAGACGAAATGATGGT } \\
\text { R: CAGATTCGGATGATGATGG }\end{array}$ & $(\mathrm{GT})_{9}$ & 56 & 239 & NA & - & - \\
\hline mPmIAC118 & $\begin{array}{l}\text { F: AGCGATTTTTGTTGTTAGCC } \\
\text { R: GTTCGGAGCATTCGTGTT }\end{array}$ & $(\mathrm{TAA})_{5}$ & 57 & 201 & 201 & 1 & 0.00 \\
\hline mPmIAC119 & $\begin{array}{l}\text { F: GCCCACGGATAAAATACC } \\
\text { R: GCATAGGAGACGGGAAGA }\end{array}$ & $(\mathrm{CA})_{11}$ & 53 & 201 & 201 & 1 & 0.00 \\
\hline mPmIAC120 & $\begin{array}{l}\text { F: GAGATTGTGGCAGGTGAA } \\
\text { R: AAAGGGAAAGCTCCAACA }\end{array}$ & $(\mathrm{AGA})_{6}$ & 55 & 176 & $162-176$ & 2 & 0.37 \\
\hline mPmIAC121 & $\begin{array}{l}\text { F: GAGTGGTTTGTGTGTGTGTT } \\
\text { R: GAGACCGTATCTTCTAAGTGC }\end{array}$ & $(\mathrm{AAT})_{13}$ & 53 & 180 & NA & - & - \\
\hline
\end{tabular}

$\mathrm{NA}=$ no amplification

\section{Characterization of aggressiveness of $P$. melanocephala}

The evaluation of symptom severity of $P$. melanocephala isolates verified with cultivars 'SP701143' (susceptible) and 'RB835486' (intermediately resistant) showed no significant variation when artificially inoculated with isolates P261 (Goianésia, GO), P273 (Jaú, SP), or P306 (Ribeirão Preto, SP), although there were differences in the severity of symptoms among the assessed cultivars (Figure 3). For 'SP701143', the mean infected leaf area was $2.8 \%$, while it was $0.73 \%$ for 'RB 835486 '. 


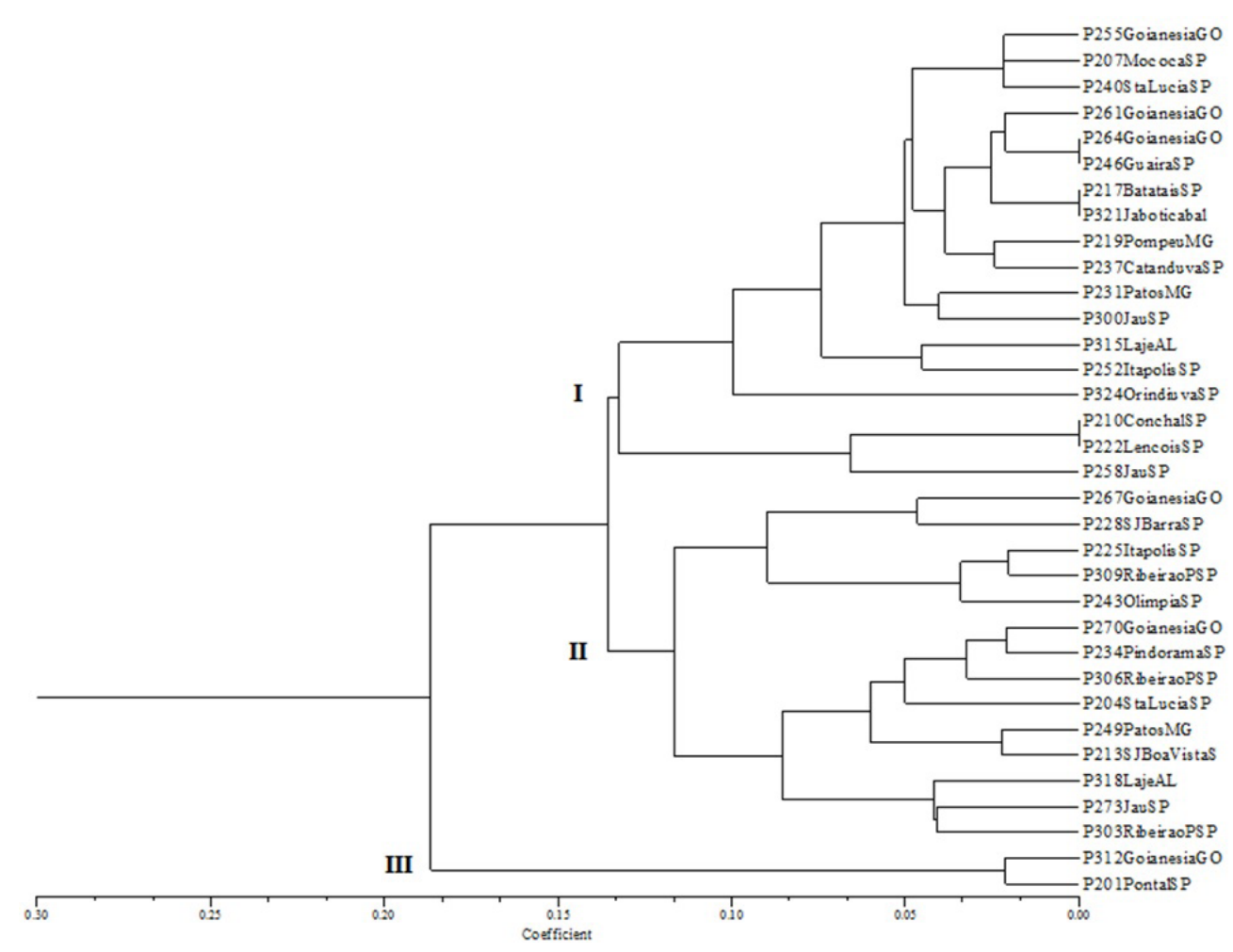

Figure 1. Estimates of genetic diversity based on Nei's unbiased genetic distance among Puccinia melanocephala isolates collected from 4 Brazilian states based on SSR polymorphisms.

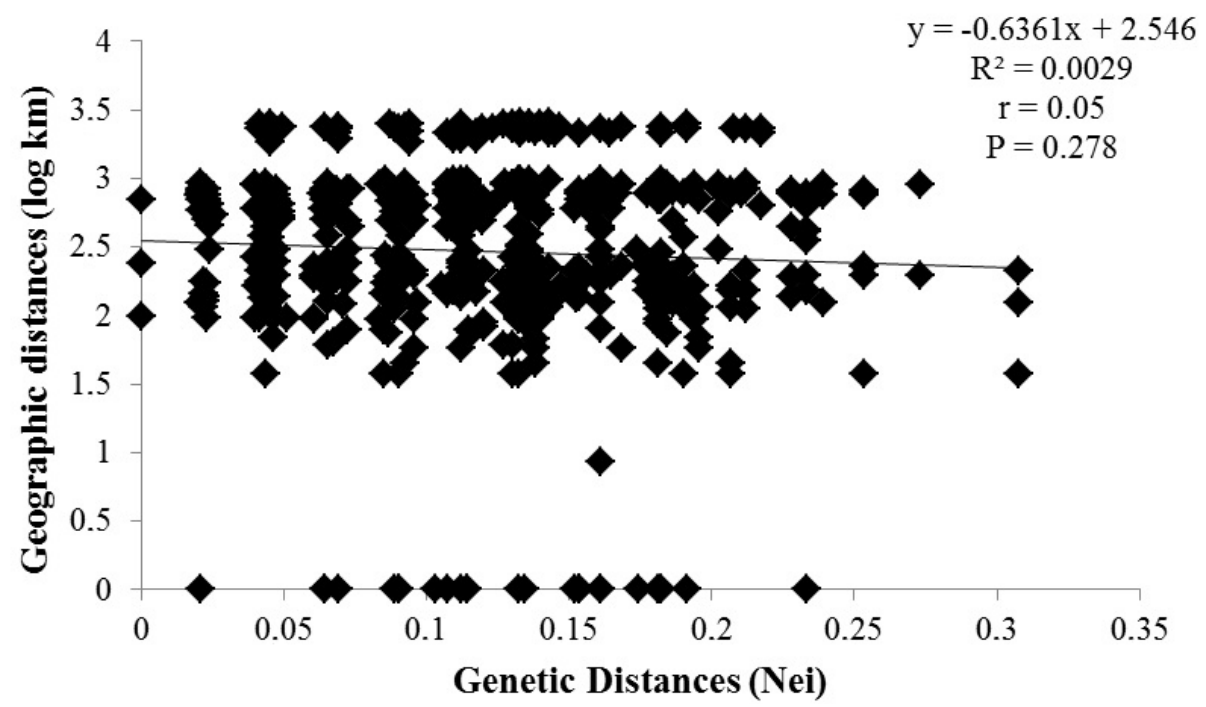

Figure 2. Correlation between Nei's genetic distances in Puccinia melanocephala isolates and geographic distances considering all pairs of locations. 


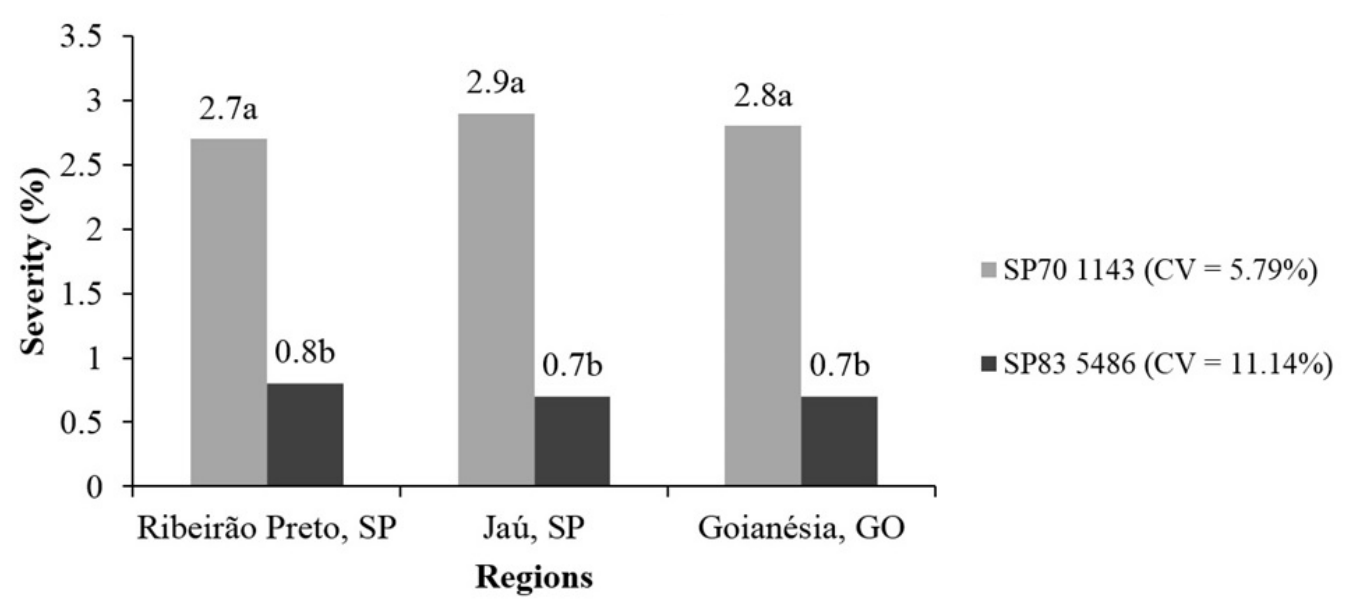

Figure 3. Brown rust severity (percentage of leaf area affected) generated by populations of Puccinia melanocephala of different locations in 2 sugarcane cultivars (same letters on the bars indicate no significant differences among according to the Tukey test at $5 \%$ probability).

\section{DISCUSSION}

Although fungal genomes show a low frequency of SSRs compared to other eukaryotes (Morgante et al., 2002), the enriched genomic library of P. melanocephala developed in this study successfully allowed the identification of polymorphic loci. The percent of polymorphic loci obtained (25\%) agreed with values reported for other Puccinia genomic SSRs, ranging from 25-50\% (Enjalbert et al., 2002; Szabo and Kolmer, 2007), and were higher than those described for expressed sequence tag-SSRs (10.2\%) (Wang et al., 2010). The number of alleles per locus detected using our SSRs was similar to those reported for expressed sequence tag-SSRs (Wang et al., 2010) and genomic SSRs (Duan et al., 2003), both for Puccinia triticina. The most abundant dinucleotide motif for P. melanocephala was GT/TG (20.7\%) and CA/AC (15.5\%). These repeats were expected because of the probes used in this study. The observation that the dinucleotide GT/TG was the most frequent in the library suggests that this motif is more abundant in the P. melanocephala genome.

Of the total of 16 loci for which amplification products were observed, $4(25 \%)$ were polymorphic and able to discriminate 28 of the $36(82.3 \%)$ isolates of $P$. melanocephala evaluated. This efficiency was higher than that obtained for Grosmannia clavigera, in which only $8(13.3 \%)$ of the 60 SSR loci tested in isolate characterization were polymorphic (Tsui et al., 2009). The failure in amplifications of 5 loci may be attributed to the presence of introns or mutations in the target region of primer annealing region (Dutech et al., 2007).

A low level of genetic diversity was observed among the isolates from 4 Brazilian states evaluated. This may be explained by dispersion mechanisms and fungus biology. Because no sexual recombination occurred, the most probable cause of the genetic diversity levels observed in this study includes constant sources of exogenous introduction of exotic, genetically distinct isolates (Virtudazo et al., 2001b), followed by mutational events. Additionally, it was not possible to cluster the isolates according to location or state of original collection. This can be explained in part by the strong flow of infected plants within the major 
sugarcane producing regions in Brazil, as well as by the long-distance dispersion ability of urediniospores, either following single aerial transport events or stepwise range expansion into new regions (Isard et al., 2011). The genetic diversity of $P$. melanocephala has been examined in several countries where sugarcane is cultivated. In Argentina, amplified fragment length polymorphism markers were used to evaluate $30 \mathrm{P}$. melanocephala isolates from 3 regions and a high level of genetic diversity was observed (Pocovi et al., 2010). In contrast, genetic characterization of Punninia kuehnii with rDNA regions revealed a low level of variability among Australian isolates, while significant differences were observed among isolates from Papua New Guinea, Indonesia, and China (Braithwaite et al., 2009).

We analyzed the severity of brown rust in 3 sugarcane isolates from the main area in which sugarcane is grown in Brazil using excised leaves and found no differences among isolates, although symptom severity varied according to the cultivar assessed. Therefore, according to the diagrammatic scale used (Amorim et al., 1987), cultivar SP70-1143 was clearly susceptible to brown rust, whereas RB835486 showed intermediate resistance for all 3 isolates observed. These results suggest that the populations of brown rust studied from Brazil were not distinct races.

The existence of P. melanocephala races is poorly defined. In Brazil, P. melanocepha$l a$ isolates from São Paulo State showed variability in aggressiveness and severity, suggesting the existence of brown rust races (Rago, 2005). In the USA, the existence of $P$. melanocephala races was described based on changes in the disease reaction in a set of resistant cultivars a few years after their release, indicating the existence of at least 4 races of brown rust (Shine et al., 2005). However, in Australia, no physiological race was identified with 12 differential cultivars when isolates from 4 regions of Queensland were inoculated on excised leaves (Taylor, 1992). The constant variations in the severity of brown rust in Australia have been attributed to changes in climatic conditions and not to the development of new races. Climatic conditions are known to be important for the initiation and intensity of epidemics caused by rust (Taylor, 1992). However, resistant clones may show increased susceptibility over time because of the variability of pathogen populations. This indicates that races of this pathogen and the resistance currently exhibited by the cultivars may change in the future (Braithwaite et al., 2009). Some studies have demonstrated that the heritability of brown rust resistance in sugarcane is high and is controlled by one or a few major effect genes (Asnaghi et al., 2001). However, other studies have shown that additional minor effect genes may also be important in rust resistance (Ramdoyal et al., 2000). Thus, rust resistance in sugarcane may be conferred through the integrated action of these genes, with major effect genes having a stronger influence or effect on resistance.

Investigating brown rust genetic variability and identifying regions with favorable climatic conditions for disease development are extremely important for the success of sugarcane breeding programs, mainly over the long term and aiding the development of new cultivars. Our results suggest that the populations of brown rust from Brazil studied are not distinct races. Therefore, genetic breeding for resistance to brown rust may be conducted in locations where climatic conditions are highly favorable to pathogen occurrence or even in controlled environments through artificial inoculation; these results are likely representative for other regions. Additionally, management strategies involving the cultivation of no more than $20 \%$ of the area with cultivars with similar reaction behavior (susceptible and intermediate) can circumvent brown rust outbreaks. The adoption of such procedures will prevent problems derived from the release of cultivars that may show changes in resistance to brown rust after its release. 


\section{ACKNOWLEDGMENTS}

Research supported by Fundação de Amparo à Pesquisa do Estado de São Paulo (\#2005/56711-7) and fellowship to Rafael F. Peixoto Júnior. It was also partially funded by CNPq (Conselho Nacional de Desenvolvimento Científico e Tecnológico). The authors give special thanks to Luciana Rossini Pinto for her help in data analysis.

\section{REFERENCES}

Aljanabi SM, Forget L and Dookun A (1999). An improved and rapid protocol for the isolation of polysaccharide- and polyphenol-free sugarcane DNA. Plant Mol. Biol. Rep. 17: 281.

Amorim L, Bergamin AF, Sanguino A, Ardoso COM, et al. (1987). Metodologia de avaliação de ferrugem da cana-deaçúcar (Puccinia melanocephala). Boletim Técnico Copersucar 39: 13-16.

Anderson JA, Churchill GA, Autrique JE, Tanksley SD, et al. (1993). Optimizing parental selection for genetic linkage maps. Genome 36: 181-186.

Asnaghi C, D'Hont A, Glaszmann JC and Rott P (2001). Resistance of sugarcane cultivar R 570 to Puccinia melanocephala isolates from different geographic locations. Plant Dis. 85: 282-286.

Botstein D, White RL, Skolnick M and Davis RW (1980). Construction of a genetic linkage map in man using restriction fragment length polymorphisms. Am. J. Hum. Genet. 32: 314-331.

Braithwaite KS, Croft BJ, Magarey RC and Scharaschkin T (2009). Phylogenetic placement of the sugarcane orange rust pathogen Puccinia kuehnii in a historical and regional context. Aust. Plant Pathol. 38: 380-388.

Creste S, Benatti TR, Orsi MR, Risterucci AM, et al. (2006). Isolation and characterization of microsatellite loci from a commercial cultivar of Musa acuminata. Mol. Ecol. Notes 6: 303-306.

Dixon LJ, Castlebury LA, Aime MC, Glynn NC, et al. (2010). Phylogenetic relationships of sugarcane rust fungi. Mycol. Progress 9: 459-468.

Duan X, Enjalbert J, Vautrin D, Solignac M, et al. (2003). Isolation of 12 microsatellite loci, using an enrichment protocol, in the phytopathogenic fungus Puccinia triticina. Mol. Ecol. Notes 3: 65-67.

Dutech C, Enjalbert J, Fournier E, Delmotte F, et al. (2007). Challenges of microsatellite isolation in fungi. Fungal Genet. Biol. 44: 933-949.

Efron B (1981). Censored data and the bootstrap. J. Am. Statist. Assoc. 76: 312-319.

Enjalbert J, Duan X, Vautrin D, Giraud T, et al. (2002). Isolation of twelve microsatellite loci, using an enrichment protocol, in the phytopathogenic fungus Puccinia striiformis f. sp. tritici. Mol. Ecol. Notes 2: 563-565.

Garcia EO, Casagrande MV, Rago AM and Massola NS (2007). Preservação de urediniósporos de Puccinia melanocephala, agente causal de ferrugem em cana-de-açúcar. Summa Phytopathol. 33: 152-156.

Isard SA, Barnes CW, Hambleton S, Ariatti A, et al. (2011). Predicting seasonal soybean rust incursions into the North American continental interior using sentinel plot monitoring, spore trapping, and aerobiological modeling. Plant Dis. 95: 1346-1357.

Mantel N and Valand RS (1970). A technique of nonparametric multivariate analysis. Biometrics 26: 547-558.

Milgroom MG and Peever TL (2003). Population biology of plant pathogens. Plant Dis. 87: 608-617.

Morgante M, Hanafey M and Powell W (2002). Microsatellites are preferentially associated with nonrepetitive DNA in plant genomes. Nat. Genet 30: 194-200.

Nei M (1973). Analysis of gene diversity in subdivided populations. Proc. Natl. Acad. Sci. U. S. A. 70: 3321-3323.

Pocovi MI, Rech GE, Collavino NG, Caruzo GB, et al. (2010). Molecular diversity of Puccinia melanocephala populations. J. Phytopathol. 158: 769-775.

Purdy LH, Liu L and Dean JL (1983). Sugarcane rust, a newly important disease. Plant Dis. 67: 1292-1296.

Rago AM (2005). Pathogenic Variability of Puccinia melanocephala and Ustilago scitaminea in the State of São Paulo. Master's thesis, Escola Superior de Agricultura "Luiz de Queiroz", USP, Piracicaba.

Ramdoyal K, Sullivan S, Lim-Shin-Chong LCY, Badaloo GH, et al. (2000). The genetics of rust resistance in sugar cane seedling populations. Theor. Appl. Genet. 100: 557-563.

Shine Junior JM, Comstock JC and Dean JL (2005). Comparison of five isolates of sugarcane brown rust and differential reaction on six sugarcane clones. Proc. Int. Soc. Sugar Cane Technol. 2: 638-647.

Szabo LJ and Kolmer JA (2007). Development of simple sequence repeat markers for the plant pathogenic rust fungus, Puccinia triticina. Mol. Ecol. Notes 7: 708-710.

Taylor PWJ (1992). Evidence for the existence of a single race of common rust caused by Puccinia melanocephala, in 
Australian sugarcane cultivars. Aust. J. Agr. Res. 43: 443-450.

Tóth G, Gáspári Z and Jurka J (2000). Microsatellites in different eukaryotic genomes: survey and analysis. Genome Res. 10: 967-981.

Tsui CK, Feau N, Ritland CE, Massoumi AS, et al. (2009). Characterization of microsatellite loci in the fungus, Grosmannia clavigera, a pine pathogen associated with the mountain pine beetle. Mol. Ecol. Resour. 9: 1500-1503.

Virtudazo EV, Nojima H and Kakishima M (2001a). Taxonomy of Puccinia species causing rust diseases on sugarcane. Mycoscience 42: 167-175.

Virtudazo EV, Nakamura H and Kakishima M (2001b). Phylogenetic analysis of sugarcane rust based on sequences of ITS, 5.8S rDNA and D1/D2 regions of LSU rDNA. J. Gen. Plant Pathol. 67: 28-36.

Wang X, Mulock B, Guus B and Mccallum B (2010). Development of EST-derived simple sequence repeat markers for wheat leaf rust fungus, Puccinia triticina Eriks. Can. J. Plant Pathol. 32: 98-107.

Weising K, Nybom H, Wolff K and Meyer W (1995). DNA Fingerprinting in Plants and Fungi. CRC Press, Boca Raton.

Whittle AM and Holder D (1980). The origin of the current rust epidemic in the Caribbean. Sugarcane Pathologists' Newslet. 24: 4-7.

Yap I and Nelson RJ (1996). Winboot: A Program for Performing Bootstrap Analysis of Binary Data to Determine the Confidence Limits of UPGMA-Based. IRRI, Manila. 